\title{
Literatur
}

1. Robins, J. und J. E. Rald, Recent Progr. Hormone Res., 13, 161 (1957). - 2. HAMolsky, M. W., M. Stein und A. S. Freedberg, J. Clin. Endocr. (Springfield) 17, 33 (1957). - 3. Ferrinr, O., G. L. Perroni, P. Biassini und M. Bestagno, Minerva Nucleare, 6, 49 (1962). - 4. Sirger, E. und A. SACrs, J. Clin. Endocr. (Springfield), 24, 313 (1964). - 5. AdaMs, R. A., N. SPECht und I. Woodward, J. Clin. Endoct. (Springfield) 20, 1366 (1960). - 6. Walfish, P. G., A. Britton, R. Volpe und C. Ezrin, Canad. Med. Ass. J., 84, 637 (1961). - 7. TAuxe, N. W., J. L. Becton und M. Y. Yamaguchr, Amer. J. Clin. Path. 39, 562 (1963). - 8. Woldring, M. G., A. BAKker und H. DoorenBos, Acta endocr. K'hrn 37, 607 (1961). - 9. SterLing, K. und M. Tabacrinik, J. Clin. Endocr. (Springfield) 21, 456 (1961). 10. McAdams, G. B. und R. F. Reinfrank, J. Nucl. Med. 5, 112
(1964). - 11. Lee, N. D., V. J. Pileggr und M. Segalove, Clin. Chem. (New York) 10, 136 (1964). - 12. F. Clark und D. B. HORN, J. Clin. Endocr. (Springfield) 26, 352 (1966). - 13. LEE, N. D., R. J. Henry und O. J. Golub, J. Clin. Endocr. (Springfield) 24, 486 (1964). - 14. Hocman, G., J. Chromatogr. (Amsterdam) 21, 413 (1966). - 15. ClaArk, F., G. Goldstein und K. R. Crispeli, J. Nucl. Med. 7, 464 (1966). - 16. SCribe, P. C., R. LaNdGRAF, H. G. HeINZE und K. SChWARZ, Klin. Wschr. 44, 69 (1966). 17. Scriba, P. C., H. G. Heinze, R. Landgrap, K. W. Frey und K. Schwarz, Klin. Wschr. 44, 131 (1966). - 18. Lissitzky, S. und J. Brsmuth, Clin. chim. Acta (Amsterdam) 8, 269 (1964). - 19. GyertyáNFY, G. und J. FöLDES, diese Z. 5, 213 (1967). - 20. Oppenheimer, J. H. und M. I. Surks, J. Clin. Endocr. (Springfield) 21,456 (1964).
Dr. G. Gyertyánfy Budapest VIII, Ungarn Korányi S-u 2/a

\section{Enzymatic Determination of Glycerol and Glyceride-Glycerol in Plasma}

\author{
By J. Parijs, F. Barbier and P. Vermeire \\ From the University of Ghent Policlinic of Internal Medicine (Director: Prof. Dr. L. Remouchamps), Ghent (Belgium.)
}

(Eingegangen am 25. Oktober 1967)

Die von Wieland beschriebene Methode für die enzymatische Glycerinbestimmung im Plasma wurde im Enteiweißungsverfahren, der Reihenfolge der Zugabe der Reagenzien und der Zeit der Extinktionsmessung vereinfacht. Die Methode wurde für die Bestimmung von Glycerid-Glycerin im Plasma erweitert.

The method described by WIELAND for the enzymatic determination of glycerol in plasma was simplified in the deproteinization procedure, the sequence of adding the reagents and the time of reading the optical density. The method has been extended to the determination of glyceride-glycerol in plasma.

The enzymatic determination of glycerol has been elaborated by WIELAND $(1,2)$ and modified by SPINELLA and MAGER (3). The latter authors extended the method to the determination of glyceride-glycerol, Glycerol is phosphorylated to L(-)-glycerol-1-phosphate by ATP and $\left.G^{1}\right)(2,4)$. Under the influence of $\alpha-G D H$, glycerol-1-phosphate and NAD are converted into DOAP and NADH (5).

An alkaline medium with an excess of NAD is used to increase the equilibrium constant of this reaction.

Finally DOAP is trapped by hydrazine $(4,6)$.

The optimal $\mathrm{pH}$ for enzyme activity of glycerolkinase is 9,$8 ; \mathrm{Mg}^{++}$is needed as an activator (4).

We modified the method of WIELAND and SPINELLAMAGER as follows:

1. deproteinization by the Somogrr procedure (7).

2. except for GDH, all reagents were added to the filtrate as a mixture and not separately.

3. the increase of optical density was measured once, one hour after adding $\mathrm{GDH}$, and not at short intervals until a maximum value was attained.

1) Abbreviations: GK = glycerolkinase (ATP: glycerol phosphotranșferase EC 2.7.1.30); $\alpha-G D H=$ Glycerolphosphate dehydrogenase (L-glycerol-3-phosphate: NAD Oxidoreductase EC 1.1.1.8); DOAP = dihydroxy-acetone-phosphate.

2) Both reagents are to be titrated one against the other.

3) Bochringer Biochimica.

\section{Methods}

\section{Reagents}

Zinc sulphate $0.25 \mathrm{~N}^{2}$ )

Sodium hydroxide $0.25 \mathrm{~N}^{2}$ )

Buffer: glycine $0.2 \mathrm{M}$; hydrazine $1 \mathrm{M} ; \mathrm{Mg}^{++} 2 \cdot 10^{-3} \mathrm{M}, \mathrm{pH} 9.8$ Store at $4^{\circ} \mathrm{C}$ in a brown bottle and prepare fresh every 4 weeks. ATP 3 ) $0.05 \mathrm{M}$

Neutralised with $1 \mathrm{~N} \mathrm{NaOH}$, the solution is stable for several months.

$\mathrm{NAD}^{3}$ ) $0.02 \mathrm{M}$

Kept frozen in suitable portions

GK-suspension $\left.{ }^{3}\right) 1 \mathrm{mg} / \mathrm{ml}$

Kept at $4^{\circ} \mathrm{C}$.

GDH-suspension $\left.{ }^{3}\right) 10 \mathrm{mg} / \mathrm{ml}$

Kept at $4^{\circ} \mathrm{C}$.

Reagent-mixture

$5.50 \mathrm{~m} l$ buffer $; 0.20 \mathrm{~m} l$ ATP $; 0.20 \mathrm{~m} / \mathrm{NAD} ; 0.04 \mathrm{~m} /$ glycerolkinase. Incubated for 15 minutes at $37^{\circ} \mathrm{C}$ immediately before use. This mixture should be used within 2 hours after its preparation.

Bloor-mixture: ethanol/diethylether 3:1 (V/V)

Silicagel Merck $\mathrm{N}^{\circ} 7729$ - particle size below $0.08 \mathrm{~mm}$. Nonactivated.

Chloroform

Ethanol

Ethanolic $\mathrm{KOH}$-solution
a) stock solution (2\%)
b) work solution $(0.4 \%)$
Acetic acid (6\%)
Petroleum ether
Sulphuric acid $0.67 \mathrm{~N}$
Sodium hydroxide $0.67 \mathrm{~N}$ 
Glycerol stock solution: $400 \mu \mathrm{mol} /$ liter

Prepared with glycerol p. a. Its water content is measured refractometrically.

\section{Procedure}

\section{Collection of sample}

Blood is drawn off in a centrifuge-tube containing $1 \mathrm{mg}$ EDTA $/ \mathrm{m} l$ blood. The plasma is immediately separated and deproteinised for the glycerol determination or extracted for the glyceride-glycerol determination.

\section{Assay of gljcerol}

Transfer to a centrifuge tube in the order listed:

$0.5 \mathrm{~m} l$ of aq. bidest; $1 \mathrm{~m} l$ of plasma; $1 \mathrm{~m} /$ of $Z$ inc sulphate solution and $1 \mathrm{~m} l$ of $0.25 \mathrm{~N} \mathrm{NaOH}$. Mix well and centrifuge after 5 minutes. Pipette the following into a cuvette: $0.5 \mathrm{~m} l$ of aq. bidest; $1.5 \mathrm{ml}$ of reagent mixture and $1 \mathrm{ml}$ of supernatant.

After incubation for $10 \mathrm{~min}$. at $37^{\circ} \mathrm{C}$, a first reading of optical density $\left(\mathrm{E}_{1}\right)$ against water is made at $340 \mathrm{~nm}$. After adding $0.02 \mathrm{ml}$ of GDH and incubation for 1 hour at room temperature, a second reading of optical density $\left(E_{2}\right)$ is made.

A blank tube, in which $1 \mathrm{~m} /$ of aq. bidest. has been substituted for the supernatant, is prepared according to the same procedure as the unknown sample.

Calculation (3):

$\frac{\Delta \mathrm{E}}{0.062} \times 0.01 \times 3 \times 3.5 \times 1000=\mu \mathrm{mol}$ glycerol $/$ liter

$\Delta \mathrm{E}=\Delta \mathrm{E}$ sample $-\Delta \mathrm{E}$ blank

For concentrations higher than $200 \mu \mathrm{mol} / \mathrm{liter}$, the supernatant should be diluted with aq. bidest. However the use of a standard curve elaborated with several dilutions of the glycerol standard solution is prefered to this formula. These dilutions are processed according to the same procedure as plasma.

\section{Assay of glyceride-glycerol}

Extract $0.75 \mathrm{ml}$ of plasma with $14.25 \mathrm{ml}$ of Bloor-mixture. Evaporate $10 \mathrm{~m} l$ of the extract, dissolve in $10 \mathrm{ml}$ of chloroform and add $0.5 \mathrm{~g}$ of silicagel. Shake for $30 \mathrm{~min}$. and evaporate $2 \mathrm{ml}$ of the chloroform extract. Add $0.7 \mathrm{ml}$ of ethanol and $0.3 \mathrm{ml}$ of $0.4 \%$ ethanolic $\mathrm{KOH}$ solution to the residue. Simultaneously a blank is set up, with only $1 \mathrm{ml}$ of ethanol added to the residue. Blank and sample are further treated in the same way. After heating for $30 \mathrm{~min}$ at $60^{\circ} \mathrm{C} ; 0.1 \mathrm{ml}$ of $6 \%$ acetic acid is added.

After evaporation in vacuo at room-temperature add $10 \mathrm{ml}$ of petroleum ether and $5 \mathrm{~min}$. later $1 \mathrm{ml}$ of $0.67 \mathrm{~N}$ sulphuric acid. Shake this mixture for $5 \mathrm{~min}$., suck off and discard the petroleum ether. Add successively in a cuvette $0.9 \mathrm{~m} l$ of aq. bidest, $1.5 \mathrm{ml}$ of the reagent mixture, $0.3 \mathrm{ml}$ of the sulphuric acid layer (containing the free glycerol of the saponified glycerides), $0.3 \mathrm{~m} l$ of $0.67 \mathrm{~N} \mathrm{NaOH} . \mathrm{E}_{1}$ is measured after mixing and incubation for $10 \mathrm{~min}$., at $37^{\circ} \mathrm{C}$. $\mathrm{E}_{2}$ is measured after adding $0.02 \mathrm{ml}$ of $\mathrm{GDH}$ and incubation at room-temperature for 1 hour. The reagent blank is identical to the one used for the glycerol determination.

Calculation

$\frac{\Delta \mathrm{E}_{1}-\Delta \mathrm{E}_{2}}{0.062} \times 0.01 \times 3 \times 33.3 \times 1000=\mu \mathrm{mol}$ glyceride-glyce$\mu \mathrm{mol}$ glyceride-glycerol $/$ liter $\times \frac{\left.876^{4}\right)}{1000 \times 10}=\mathrm{mg} / 100 \mathrm{~m} l$ trigly-

$\Delta \mathrm{E}_{1}=\Delta \mathrm{E}$ after saponification $-\Delta \mathrm{E}$ reagent blank

$\Delta \mathrm{E}_{2}=\Delta \mathrm{E}$ without saponification $-\Delta \mathrm{E}$ reagent blank

For concentrations over $1900 \mu \mathrm{mol} /$ liter glyceride-glycerol or $165 \mathrm{mg} / 100 \mathrm{ml}$ triglycerides the determination should be repeated, using 0.5 or $1 \mathrm{ml}$ of chloroform extract. However the use of the same standard curve as used for the glycerol determination is

4) Average molecular weight of plasma triglycerides (3). indicated. The figure obtained on the absciss, multiplied with 9.5 gives $\mu \mathrm{mol}$ glyceride-glycerol/liter, and multiplied by 0.83 , gives $\mathrm{mg} / 100 \mathrm{~m} /$ triglycerides.

\section{Results and Discussion \\ Deproteinising agent}

Deproteinization with Zinc sulphate and $\mathrm{NaOH}$ does not result in values too low due to adsorption of glycerol to the precipitate or by inhibition of the enzymatic reaction. Indeed, whether the glycerol standard solution is treated with deproteinizationreagent or not, has no influence on the results obtained. However an excess of Zinc sulphate inhibits the enzymatic reaction. See table 1.

Tab. 1

The influence of deproteinising agent and excess Zinc sulphate on the enzymatic determination of glycerol. Glycerol standard solution, $200 \mu \mathrm{mol} / l, \Delta \mathrm{E}$ without deproteinization $=0.115$, titer $\mathrm{NaOH}=0.250$

\begin{tabular}{cc}
\hline Titer Zinc sulphate solution (x) & $\Delta \mathrm{E}$ \\
\hline 0.225 & 0.115 \\
0.250 & 0.115 \\
0.275 & 0.105 \\
0.300 & 0.059 \\
0.325 & 0.015 \\
\hline
\end{tabular}

\section{Incubation time}

Incubation of the supernatant with the reagent mixture for more than 10 minutes is not necessary. Indeed the affinity of glycerolkinase for glycerol is such that the reaction comes to an end very quickly (2).

Deviation of the standard curve from the theoretical curve must be attributed to the inhibition of glycerophosphatedehydrogenase. The optical density reading over a $70 \mathrm{~min}$. period proves that a maximum optical density is ensured, one hour after the addition of GDH. See figure 1.

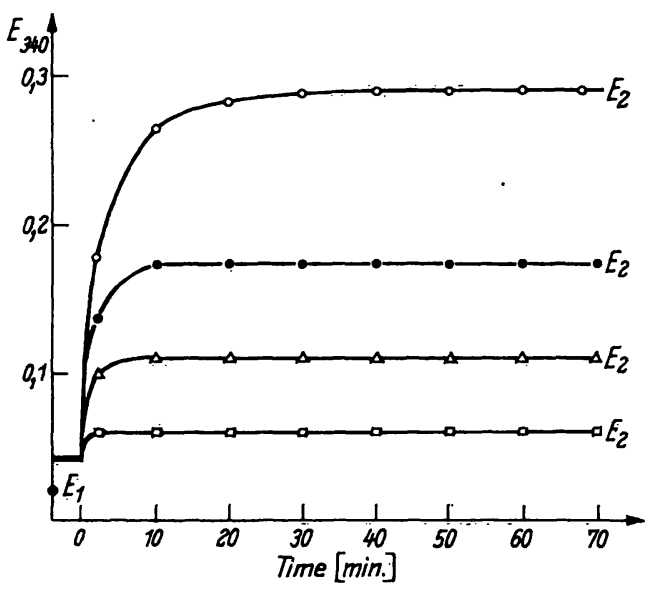

Fig. 1

Relationship of absorbance to time of incubation $\therefore$ ○ $400, \cdot-200, \Delta-\Delta 80 \mu \mathrm{mol}$ glycerol/liter, $\square-\square$ blank

\section{Stability of the reagent mixture}

The reagent mixture is stable for 2 hours only. The older the reagent mixture, the higher $E_{1}$. Values for $E_{1}$, obtained with the reagent mixture freshly prepared, after 2 and after 5 hours storage, were respectively 
$0.032 ; 0.060$ and 0.121 . The final result with a 2 hours old reagent mixture, is still correct because $\mathrm{E}_{2}$ increases to the same extent as $E_{1}$. But if an 5 hours old reagent mixture is used, the results are approximatively $15 \%$ too low.

With the aging of the reagent mixture a non enzymatic reaction presumably occurs between the hydrazine and NAD (8).

\section{Standardisation}

Comparison of the standard curve with the theoretical curve as calculated from the formula clearly indicates that the reaction is quantitative up to a concentration of $200 \mu \mathrm{mol} /$ liter. For higher concentrations the standard curve should be used. See figure 2 .

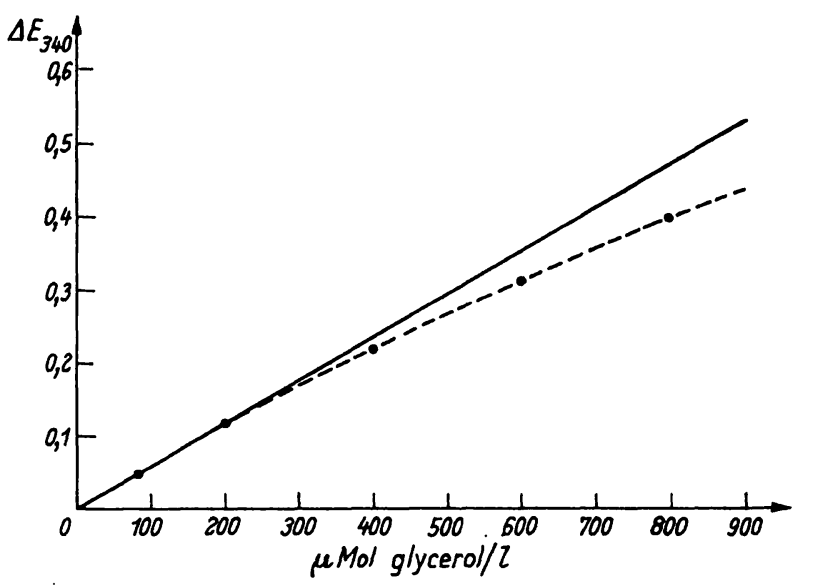

Fig. 2

Comparison of the standard curve with the theoretical curve

\section{Specificitv of the glycerol assay}

Lactate does not interfere if GDH is not contaminated with lactic dehydrogenase. This can be checked by treating an aqueous solution of lactate by the same procedure as for the glycerol standard solution. With this technique the sum of glycerol and glycerol-1phosphate is measured. L- $\alpha$-glycerophosphate is not normally present in human plasma. But it appears after injection of fructose (1). However this metabolite can be determined separately by omitting glycerokinase from the reagent mixture.

\section{Reproducibility}

The reproducibility of the method evaluated by ten repeated analyses on one particular plasma specimen at a level of $158.8 \mu \mathrm{mol} /$ liter resulted in a standard deviation of $3.9 \mu \mathrm{mol} /$ liter.

The percentage recovery of glycerol added to plasma varies from 97 to $101 \%$.

\section{Stability of glycerol in deproteinised plasnia}

After deproteinization, the glycerol content does not change on storage. No differences were observed between determinations made immediately after deproteinization and those after storing the deproteinised sample for 3 days.

\section{Glyceride-glycerol assay}

The extraction of lipids, the removal of the phospholipids and the hydrolysis of the glycerides which preceed the enzymatic reaction, have been critically analysed in a previous publication (9). A tristearate solution of $120 \mathrm{mg} / 100 \mathrm{ml}$ gave values of: $119.8 ; 122.1 ; 120.5$; 117.7 and 120.3. The mean of ten determinations of glyceride-glycerol content performed on ten different samples, was $95.4 \mathrm{mg} / 100 \mathrm{~m} /$ for the colorimetric method (9) and $94.5 \mathrm{mg} / 100 \mathrm{~m} l$ for the enzymatic method.

\section{References}

1. WIELAND, O. Biochem. Z. 329, 313 (1957). - 2. WIELAND, O. and M. SuYTER, Biochem. Z. 329, 320 (1957). - 3. SPINELLA, C. J. and M. Mager, J. Lipid Res. 7, 167 (1966). - 4. Bublitz, C. and E. P. KenNedy, J. biol. Chemistry, 211, 951 (1954). - 5. Baranowski, T., J. biol. Chemistry, 180, 539 (1959). - 6. Hohorst,
M. J., Methoden der Enzymatischen Analyse p. 215, Hrsg. H.-H. Bergmeyer, Verlag Chemie, GmbH, Weinheim (1962). - 7. Somogyr, J., J. biol. Chemistrȳ, 86, 655 (1930). - 8. Pfleiderer, G. and K. Dose, Biochem. Z. 326, 436 (1955). - 9. PARIJS, J. and F. BARBIER, Pharmaceut. tschr., Antwerpen, 44, 81 (1967).
Dr. J. Parijs

Akademisch Ziekenhuis 115, De Pintelaan Ghent, Belgium 